\title{
Biodiversity conservation in climate change driven transient communities
}

\author{
Peter Schippers ${ }^{1}$ (D) Euridice Leyequien Abarca ${ }^{2}$. Jana Verboom ${ }^{1,3}$. \\ G. W. Wieger Wamelink ${ }^{1}$ (D) . Claire C. Vos $^{1} \cdot$ Willem F. de Boer ${ }^{4}$ (D) . \\ Jeffrey A. Harvey ${ }^{5,6}$ (D) . Tijl Essens ${ }^{7}$. Carla J. Grashof-Bokdam ${ }^{1}$. \\ Michiel F. WallisDeVries ${ }^{8,9}$ (D) Marleen M. P. Cobben ${ }^{5,10}$
}

Received: 22 September 2020 / Revised: 7 June 2021 / Accepted: 28 June 2021 /

Published online: 13 July 2021

(c) The Author(s) 2021

\begin{abstract}
Species responding differently to climate change form 'transient communities', communities with constantly changing species composition due to colonization and extinction events. Our goal is to disentangle the mechanisms of response to climate change for terrestrial species in these transient communities and explore the consequences for biodiversity conservation. We review spatial escape and local adaptation of species dealing with climate change from evolutionary and ecological perspectives. From these we derive species vulnerability and management options to mitigate effects of climate change. From the perspective of transient communities, conservation management should scale up static single species approaches and focus on community dynamics and species interdependency, while considering species vulnerability and their importance for the community. Spatially explicit and frequent monitoring is vital for assessing the change in communities and distribution of species. We review management options such as: increasing connectivity and landscape resilience, assisted colonization, and species protection priority in the context of transient communities.
\end{abstract}

Keywords Adaptability · Dispersal · Extinction · Greenhouse gas · Interactions · Mobility

\section{Introduction}

The increase of greenhouse gas concentrations caused by human activities enhances the absorption of radiation in the atmosphere leading to an elevation of air temperatures and changing precipitation patterns (Suggitt 2017; Felton et al. 2020). The land surface has warmed on average by $1.53{ }^{\circ} \mathrm{C}\left(1.38-1.68^{\circ} \mathrm{C}\right)$ over approximately the last 120 years, with an acute warming observed from 1980 onwards (IPCC 2019). The last several years are also the

Communicated by Dirk Sven Schmeller.

Peter Schippers

Peter.Schippers@wur.nl

Extended author information available on the last page of the article 
Fig. 1 Scheme describing climatic impacts on species survival

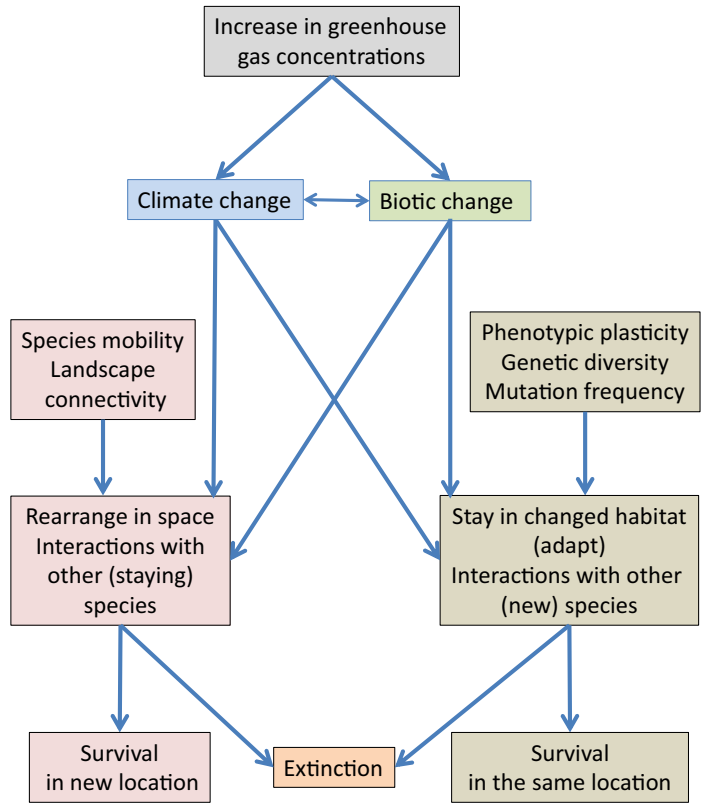

warmest ever recorded (IPCC 2019). Anthropogenic climate change has affected Earth's biota on all continental territories (Foden, 2019; Hoffmann et al. 2019; Visser and Gienapp 2019). These changes affect species survival and colonization both directly and indirectly. This may disrupt food webs, change competitive interactions between species, and put major stress on species survival (Bowers and Harris 1994; Davis et al. 1998; Ings 2009; Visser and Gienapp 2019). Species respond to climatic change by shifting their distributions and/or adapting and surviving in their changing habitats (Bonebrake, 2018; Foden et al. 2019; Hulme 2005; Parmesan 2006; Schippers et al. 2011), or else fail to adapt and become extinct (Keith 2008; Tomiolo and Ward 2018) (Fig. 1). Species may adapt to new conditions through phenotypic plasticity (i.e., behavioural, morphological or physiological responses to environmental change) or by selection for beneficial and heritable traits (Lawler 2009; Visser 2008) (Fig. 1). Alternatively, 'spatial escape', a rearrangement in space, depends on species mobility, geographical possibilities and landscape connectivity (Schippers et al. 2011) (Fig. 1). This will only be successful if potential habitat becomes suitable for colonizing species, and if the colonizing species can deal with the community formed by both the resident and other newly colonizing species (Pearson and Dawson 2003). All in all, climate change triggers a cascade of processes inducing changes in species distribution and community composition (Fig. 2) and may cause local and even global extinction of species (Figs. 1, 2). We call these changing communities 'transient', i.e. communities with a constantly changing species composition and equilibrium. In this paper, we disentangle the mechanisms and consequences of climate change for terrestrial species in these 'transient' communities and explore the consequences for biodiversity conservation. 


\section{How does the increase of greenhouse gas emissions induce transient communities?}

\section{Direct effects of greenhouse gases}

Greenhouse gases are not known to have any direct effects on terrestrial animal species at the projected concentrations. For terrestrial plants, however, the increase in atmospheric carbon dioxide is expected to enhance the internal $\mathrm{CO}_{2}$ concentration in leaves causing higher photosynthetic rates (Lloyd and Farquhar 2008; Zotz et al. 2005). This decreases the water loss per unit carbon gain and thus increases the water use efficiency, enabling plants to survive drier conditions (Battipaglia et al. 2013; Lloyd and Farquhar 2008; Soh, 2019; Zotz et al. 2005). Although the destiny of these assimilates is not always clear (Jiang, 2020), this $\mathrm{CO}_{2}$ fertilisation effect is expected to stimulate plant growth and may result in a higher vegetation growth and cover (Drake et al. 1997; Schippers et al. 2015a). Moreover, plants differ in their response to $\mathrm{CO}_{2}$ elevation. For example, $\mathrm{C} 3$ and $\mathrm{C} 4$ plants differ with respect to their $\mathrm{CO}_{2}$ assimilation at various temperature levels; $\mathrm{C} 3$ plants (e.g. all woody vegetation and most other plants of the temperate and boreal zone) profit more from $\mathrm{CO}_{2}$ fertilisation than C4 species (e.g. many tropical grasses) (Poorter 1993; Wand et al. 1999). Consequently, increased atmospheric $\mathrm{CO}_{2}$ favours tree cover in savannah systems at the cost of grasses (Bond et al. 2003). This example shows that increasing $\mathrm{CO}_{2}$ concentration can directly affect vegetation structure inducing habitat changes affecting species vital rates and ultimately their distribution and survival. Another effect of the increase in $\mathrm{CO}_{2}$ is that it changes the plant's stoichiometry resulting in relatively low nutrient-carbon ratios of the plant's tissue (Huang et al. 2015). Because herbivores are dependent on these nutrients, the low concentrations may affect their growth and reproduction (Yuan and Chen 2015) in turn altering the food web of the community (Welti et al. 2020).

Fig. 2 Factors affecting the number of species in transient communities, + predominantly an increasing effect of factor on introductions or extinctions, predominantly a decreasing effect on introductions or extinctions

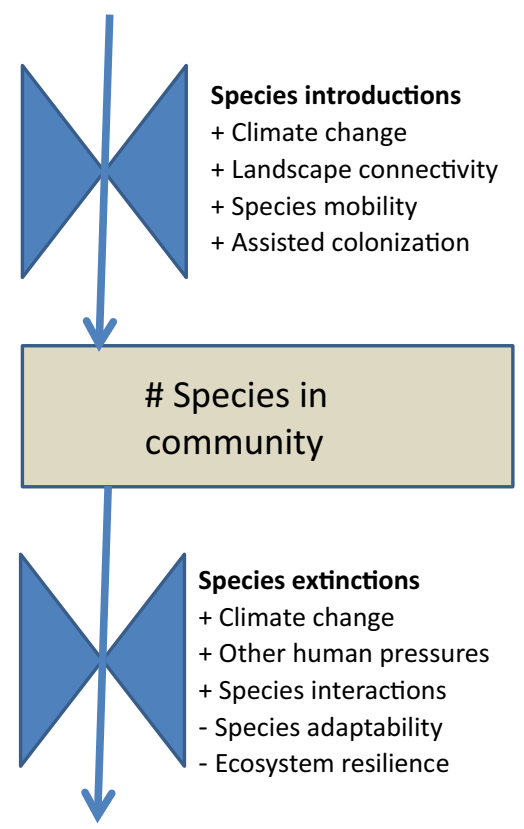




\section{Direct effects of climate change}

Greenhouse gases absorb radiation in the thermal infrared range and therefore increase the atmospheric temperature. The temperature rise is affecting the Earth's weather system with changes in precipitation patterns as well as wind directions and speeds (IPCC 2014), changing species habitats. Additionally, climate change gives rise to an increase in extreme weather events (Coumou and Rahmstorf 2012; IPCC 2014, 2019; Kendon et al. 2014; Verboom et al. 2010). Temperature is a strong determinant in the spatial distribution of species (Araujo et al. 2006; Green et al. 2008; Parmesan 1999; Waldock et al. 2018). Species have a specific temperature response with respect to survival and reproductive output. Especially the length and severity of winter in combination with species adaptations to the cold determine the poleward distribution and upper elevational limits of most species (Parmesan et al. 2000). In contrast, extreme summer temperatures and droughts govern the lower elevational boundaries and the species distribution towards the equator (Franco 2006; Jiguet et al. 2006). It is important to note that species differ in the specific nature of their temperature tolerance and response, and consequently will respond differently to change.

Models predict that precipitation regimes will change due to climatic warming (IPCC 2014, 2019). Decreases and increases in rainfall amount and frequency are expected in large parts of the world and recent studies suggest that the intensity of rainfall events is also changing (Felton et al. 2020; Myhre 2019). The anticipated magnitude of precipitation change varies between climate change scenarios. In the Representative Concentration Pathways (RCP) 2.6 scenario $\left(2{ }^{\circ} \mathrm{C}\right.$ increase in 2100$)$, local changes in precipitation are expected between -20 and $+20 \%$. In the RCP 8.5 scenario $\left(4.3{ }^{\circ} \mathrm{C}\right.$ increase in 2100) precipitation changes between -30 and $+60 \%$ are expected (IPCC 2014). Precipitation is the other important factor determining species distribution (Illan et al. 2014). Especially plant species will be sensitive to changes in precipitation because the water uptake and transpiration determine their growth rate (Felton et al. 2020; Schippers et al. 2015a; Wu et al. 2011). In general, wetland species like amphibians will suffer from precipitation reduction (Griffiths et al. 2010) whereas precipitation increase will stimulate the abundance of wetland species (Lawler et al. 2009). For specialists of dry ecosystems, we expect that reduced and increased precipitation both have a negative effect on their abundance because precipitation decrease in dry environment induces desertification and species loss (Zhang et al. 2020, 2019). Since there is a large variation in size, behaviour, morphology and physiology of community members we expect species to respond differently to temperature and precipitation change. This will drive community change (Williams and Jackson 2007) and induce transient communities. Although precipitation and temperature data enable researchers to predict the distribution of species (Harrison et al. 2006; Illan et al. 2014) it is not always clear whether this distribution is solely due to direct effects of both precipitation and temperature, or also due to biotic conditions such as co-determining species. Moreover, the predictions are based on extrapolation of regression models with relations based on data from the past in relatively constant conditions, these equations may not be valid for transient communities where species dynamics and interactions co-determines species presence.

Climate change gives rise to an increase in the frequency, duration and intensity of extreme weather events (Coumou and Rahmstorf 2012; Harvey et al. 2020; IPCC 2014, 2019; Kendon et al. 2014; Verboom et al. 2010). Results of observational studies show that in many regions variation in precipitation is amplified, while more temperature 
extremes are expected (Easterling et al. 2000). These extreme weather events may affect population survival (Lawson et al. 2015). There is evidence that periods of high temperatures and drought pose greatest risks on species survival, but also indirectly through forest fires (as we have seen recently in Australia in the 2019-2020 summer and more recently in the Pantanal, Brazil) and melting permafrost (Jorgenson 2010; Randerson 2006).

\section{Effects of biotic interactions}

As argued above, increase of atmospheric concentrations of $\mathrm{CO}_{2}$ and attendant climatic changes affect species abundance and survival. In ecosystems, however, species are interdependent through food webs (herbivory, predation, foraging), competition for resources, pollination, and complex interactions such as symbiotic and parasite-host interactions. In the food chain, some species are specialists (eating only a limited number of species) whereas others are generalists (able to switch between alternative food sources). Some animals moreover shape the environment for other animals, making nesting holes or building (termite) mounds, or keeping the grass short. Climate change thus not only affects species directly by changing their physical conditions, but also by changing their community structure (see Box 1 for an overview). For instance, precipitation and temperature change may alter the composition of plant species which in turn affects herbivore species reproduction and survival which then in turn impacts reproduction and survival of their predators (Halpin 1997; Harvey 2015; Preston et al. 2008; Schleuning, 2016). These biotic changes may alter the suitability of a habitat for a species even if the abiotic conditions are not pushed beyond its tolerance levels (Brooker et al. 2007). Species respond to climate change in a unique, species-specific way with respect to adaptations and range shifts. Moreover, species are linked by interspecific interactions, so the change in abundance in one species will affect presence and abundance of other species. Thus, direct effects of $\mathrm{CO}_{2}$ increase and changes in abiotic conditions induce biotic changes which affect community composition, thereby inducing changes in the presence and abundance of interacting species. Furthermore, newly colonizing species and species going extinct may disrupt the trophic structure and competitive relations in the community (Dunne and Williams 2009; Lurgi et al. 2012; Woodward et al. 2012).

\section{Box 1: Examples of climate change affecting species interactions}

- Plant-herbivore:

- Directions in range shift of host plant and butterfly host differ (Schweiger et al. 2008)

- Phenological responses of host plant and butterfly host differ causing a mismatch with host plant availability (Cerrato et al. 2016) or detrimental cooling of microclimate (Wallisdevries and Van Swaay 2006)

- Plant-herbivore interactions change due to changes in food quantity and quality (Zhu et al. 2015) 
- Host-parasitoid:

- Temporary escape from natural enemies in host butterfly under range expansion from resident parasitoid (Menendez et al. 2008)

- Increased parasitism from expanding generalist parasitoid on resident butterfly host (Gripenberg et al. 2011)

- Predator-prey

- Environmental change alters predator-prey interactions (Harmon et al. 2009)

- Adaptive phenological mismatches of birds and their food in a warming world (Both et al. 2006; Visser et al. 2009)

- Plant-pollinator:

- Phenological shifts caused by climate change disrupts plant and pollinator interactions (Memmott et al. 2007)

- Plant competition:

- Competing peat-forming mosses respond differently to effects of enhanced precipitation (Sonesson et al. 2002)

- Climate change affects competitive species interactions in an alpine plant community (Klanderud 2005)

- Animal competition:

- Climate change alter the competitive interactions in forest birds (Wittwer et al. 2015)

- Community interactions:

- Contrasting responses across taxonomic realms of species with different thermal niches (Bowler, 2017)

- Plant-Herbivore-Parasitoid imbalances due to disruption of synchrony, divergence in thermal preferences (Hance et al. 2007)

- Tree species response is expected to codetermine bird distribution under climate change (Matthews et al. 2011)

- Precipitation change alters plant and invertebrate species interactions in Californian grasslands (Suttle et al. 2007)

\section{Transient communities}

So, climate change can trigger cascading extinctions and introductions of new species changing the community structure constantly (Alexander et al. 2015; Gilman et al. 2010). These changes in community structure can be abrupt when environmental variables pass certain tipping points and ecosystems flip to alternative states (Amigo 2020; Osland, 2020; Scheffer et al. 2001). Additionally, extinction debts (Butterfield et al. 2019; Rumpf, 2019; Tilman et al. 1994) and time lags may exist between changes in climate and the direct and indirect responses of species. For these communities that have constantly changing 
composition and structure we introduce the term'transient communities'. We expect that most communities have or will become transient and that many species that live in these communities have difficulty to survive the transient dynamics. In contrast to non-transient communities, transient communities have a high extinction and colonization rate resulting in a more dynamic species composition (Fig. 2).

In the past, due to slow environmental changes or even by neutral species replacement (Hubbell 2005), community composition changed slowly and was expected to be close to equilibrium. Nowadays, however, climate change together with other human induced pressures result in fast environmental change (Travis 2003). As a result, equilibria are on the move which makes community dynamics largely unpredictable (Cenci and Saavedra 2019). This may induce "Novel Communities" census Hobbs (2006); communities that did not exist previously and arise through human action, environmental change, and the impacts of the deliberate and inadvertent introduction of species from other regions (Hobbs et al. 2006). The concept of Novel Communities suggests that this new state is semi-permanent. In contrast, the concept of transient communities emphasizes that these communities are changing constantly. So, when distinguishing new community states, we should be very aware of their temporary status.

\section{Species responses to climate change}

\section{Rearrangement in space}

Current climatic change is widely recognized as one of the main forces driving changes in the distribution of species. Mobile species from a wide range of taxa show distribution shifts resulting from climate change (Hickling et al. 2006; Hill et al. 2016; Mason et al. 2015). Conditions generally become more suitable in the poleward direction whereas they become unsuitable in the equatorial direction (Thomas et al. 2006). Similar changes are seen over elevational gradients (Kuhn and Gegout 2019). However, rearrangement in space requires the presence of suitable habitat, connectivity, species mobility, and successful population establishment (Schippers et al. 2011). This is especially problematic in humandominated landscapes where habitat is scarce and urban areas and infrastructure limit population expansion (Arevall et al. 2018; Opdam and Wascher 2004; Travis 2003). However, large natural barriers, such as seas and mountain ridges can also block poleward expansion for terrestrial species (Keith et al. 2011; Robillard et al. 2015; Roratto et al. 2015). In addition, range shifts can have genetic and evolutionary consequences (Excoffier et al. 2009; Lee-Yaw et al. 2018) such as loss of genetic diversity (Cobben et al. 2011), gene surfing (Demastes et al. 2019; Travis et al. 2007) and spatial sorting (Cobben et al. 2015; Shine et al. 2011), which may hinder the possibility and flexibility to colonize in new habitat patches. There might also be positive effects of this spatial escape, because when a species is more mobile than a parasite, a predator or a competing species, this species is, at least temporally, released from negative species interactions (Carrasco 2018; Menendez et al. 2008). Mountain species should move to higher altitude to escape climatic warming. Here distances are small compared to latitudinal migration, but lack of space at higher altitudes can hinder these expansions (Essens et al. 2017). Successful rearrangements in space depend on species mobility and geographical conditions and are only effective if the new habitat is suitable for these immigrating species, including interactions in the new community, which itself consists of both novel and local species (Memmott et al. 2007; Preston et al. 2008; Tylianakis et al. 2008). So, species mobility is key for the persistence of species 
that are not able to adapt (Arevall et al. 2018; Bourne et al. 2014; Cormont et al. 2011). Given the concept of transient communities mobility differences are a key factor driving community change. Furthermore, high mobility enables species not only to select for suitable abiotic conditions but also for suitable communities and biotic conditions.

\section{Adaptation}

Rapid adaptation to climatic changes is mostly associated with populations on the edge of the species range (Angert et al. 2020; Logan et al. 2019; Rehm et al. 2015). Species range expansions are expected at the poleward or uphill part of the species' distribution where environmental constrains are released. At the equatorial or downhill end of the range habitat is expected to become less suitable. Here, species can stay and adapt to the changing environment by phenotypic plasticity, selection, epigenetic changes or evolutionary adaptation (Charmantier et al. 2008; Chown et al. 2007; Richards, 2017; van Asch et al. 2013).

Phenotypic plasticity is the ability of an organism to change its behaviour, morphology or physiology in response to stimuli or inputs from the environment. For example, the capacity for birds to lay their eggs earlier in the year as a response to higher temperatures. Phenotypic plasticity has been regarded as one of the most important mechanisms to cope with rapid climate change for many species, especially on the short term (Matesanz and Ramirez-Valiente 2019; Merila 2012; Seebacher et al. 2015). Selection for suitable genotypes that are already present is an alternative way to deal with changing conditions. However, it is especially important at the core of the distribution range where the genetic diversity is high. There is growing evidence that epigenetics contribute to plant phenotypes, with important consequences for adaptation to novel conditions and species distributions (Richards et al. 2017). Micro-evolutionary dynamics play an important role in the adaptation to climate change, increasing the ability of species to survive (Bourne et al. 2014). Genetic changes can occur through the selection of thermal performance related traits, such as changes in the critical thermal maximum (Skelly et al. 2007). However, these evolutionary changes may not come fast enough to keep up with the rate at which global climate change is occurring (Lasky 2019; Nadeau and Urban 2019; Penuelas et al. 2008). Moreover, the rate of evolutionary responses may decline through time (Kinnison and Hendry 2001), and antagonistic genetic correlations among traits can constrain evolution (Etterson and Shaw 2001). (Micro-) evolutionary adaptations, including selection for increased phenotypic plasticity, take at least some generations, while the surge of new traits to be selected for can be expected to take even longer. So here we face the danger of Darwinian extinctions, meaning that in many cases we cannot expect that (micro-) evolutionary adaptations and selection will be fast enough to allow survival of populations (Holt 2003; Meester et al. 2018; Razgour 2019).

In the context of transient communities, species with high adaptability should be tolerant, plastic and/or genetically diverse with respect to abiotic climatic parameters, but should also be able to deal with the changed community structure and new biotic conditions (Lenoir and Svenning 2015; Lindner, 2010; MacLean and Beissinger 2017).

\section{Species traits and extinction rates}

From the preceding sections, we can conclude that mobility and adaptability are key traits for species to deal with both abiotic and biotic change. We expect general extinction for species with low adaptability and mobility because these species cannot cope or escape. Local extinction is to be expected for species with low adaptability and high mobility 


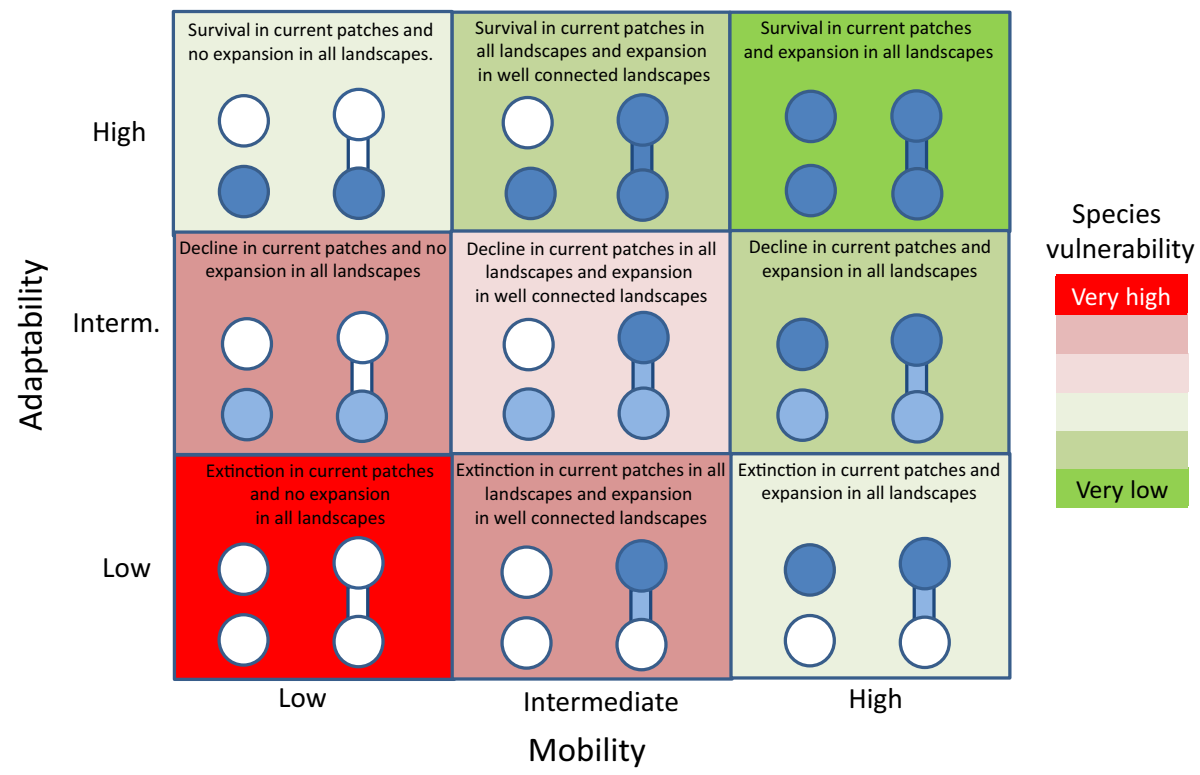

Fig. 3 Expected species vulnerability to climate change affected by adaptability and mobility in poorly and well-connected landscapes. Landscapes are simplified in to two habitat patches, the lower one is a currently occupied patch, and the top one represents a poleward patch to be colonized. Well- connected landscapes are illustrated by a corridor. Patch colour indicates the expected effect of climate change: white habitat patches are extinct or not colonized, light blue patches have marginal survival and lower population levels, and dark blue illustrates a surviving or successfully colonised populations

(Fig. 3). We expect, however, low extinction risks in species that combine high mobility with high adaptability (Fig. 3). Species with intermediate adaptability can survive in resilient landscapes that can buffer impacts of climatic change by habitat heterogeneity (see paragraph "Increase ecosystem resilience") while species with intermediate mobility survive in well-connected landscapes (Fig. 3).

\section{Species conservation in transient communities}

Because species differ in response to abiotic and biotic change, these changes induce transient communities with constantly changing species composition due to colonization and extinction events. Biodiversity management recommendations for climate change mitigation mostly ignore species interactions (Bonebrake et al. 2018; Heller and Zavaleta 2009). We showed that climate change induces transient communities, communities in which increase in $\mathrm{CO}_{2}$, abiotic and biotic changes affect complex interactions between species determining the survival and colonization of new species (Fig. 2). This may affect the success of conservation approaches that focus on single species in specific locations. These approaches mostly use a static past situation as a reference and would be overlooking the consequences of species interactions and biotic change on species survival, as well as the spatial consequences of climate change (Brambilla 2020; Engelhardt et al. 2020; Hobbs et al. 2009). The expected outcome of these approaches may be too optimistic because they ignore the effects of codetermining species while a static approach ignores community 
change. Instead, we show in the following paragraphs, that conservation measures should focus on climate change mitigation in the light of transient communities with constantly changing species composition and interactions.

\section{Reduce greenhouse gas emissions}

Greenhouse gas emission is the main driver determining climate and community changes. It enhances species movement to cooler locations (poleward, uphill) causing the colonization of new species and the loss of established species in transient communities. Therefore the reduction of greenhouse gas emissions should have priority in every conservation management program because it mitigates the speed of change and species loss in communities (Warren et al. 2018). This is even more important in transient communities because the interactions between species also determine survival. Slower climate change simply means less stress and dynamics for communities and provide time for species adaptation and species movement.

\section{Reduce other human pressures}

Climate change is the result of global emissions that cannot be managed locally. In transient communities other human induced pressures, like disturbances, introduction of invasive species and nutrient loads, generally exacerbate extinctions (Fig. 2), but occur on a more local scale and are often more manageable than global emissions. Moreover, these pressures may affect population sizes within the community which reduce species mobility and resilience (Fernandez-Chacon, 2014; Schippers et al. 2011; Wilson et al. 2010). Therefore, it is important to mitigate other human-induced factors to reduce the total pressure on transient communities already under stress by climate change.

\section{Increasing monitoring effort}

Management thinker Peter Drucker is often quoted as saying that "you can't manage what you can't measure." In transient communities we expect rapid change in species composition, abundance and distribution. To keep track of these changes, monitoring effort should be intensified. As it is impossible to measure all processes and interactions, setting up a monitoring programme for species composition, abundance and distribution is essential (O'Connor et al. 2020). The species composition, abundance and distribution merely serve as an indicator for the community status and serve as a proxy for the state of the interactions. A way of quantifying the change of species composition in transient communities is the Biological Novelty Index (Schittko 2020). This index keeps track of functional changes in communities while taking the species abundance into account. We live in interesting times, and change is going to come in many expected and unexpected forms. Having monitoring schemes and action plans ready can help to prevent ecosystem collapse and/or largescale biodiversity loss due to a combination of climate change and other human-induced pressures. For example, when detecting invasive species, early detection and management measures can help stop the invasive species from spreading. 


\section{Assess species vulnerability}

It is important to assess which species are particularly vulnerable in terms of mobility and adaptability (see chapter 3 ). We expect species with low adaptability and mobility to be likely candidates for extinction globally, whereas species with low adaptability may only become extinct locally. This might initiate communities to become transient by cascading extinctions and new introductions in open niches. Assessing mobility is relatively easy, as the responsible traits are often visible, such as the possession of wings or airborne propagules. Assessing species adaptability is, however, difficult because it is involving species genetics and plasticity with respect to temperature and precipitation. A large species distribution range is likely an indicator of high adaptability and mobility, as it reflects a species' tolerance to a variety of environmental conditions and biological constrains as well as the ability to reach suitable habitats.

\section{Study species interactions}

In the light of transient communities, species protection priority is not only determined by its own adaptability and mobility, but also by those of interacting species. Here, the food web, i.e. the competing, facilitating or otherwise interacting species co-determine the survival of species (Kaur and Dutta 2020; Van der Putten et al. 2010). So, knowledge about species interactions is crucial. If we consider species protection in transient communities, we should therefore also consider how important species are for the survival of other species of the community. If many community members are strongly dependent on the presence of a certain species, the protection of such a keystone species is of utmost importance because the survival of many species depends on its presence. Clearly keystone species that are vulnerable to climatic change are priority candidates in conservation planning.

\section{Protect species globally not locally}

Current conservation practice is usually focused on protecting what is there (current species distribution areas, biodiversity hotspots, nature reserves). Conservation professionals however should be aware of the fact that nowadays communities are becoming more and more transient, meaning that some species will go extinct locally, no matter how hard we try to save them, and new species will establish (Harrison et al. 2006) (Fig. 2). Rigid local species conservation aims with respect to species composition, such as the European Natura 2000 network, are therefore inadequate in the long run, since species composition will inevitably change locally (Harris et al. 2019; Kovac et al. 2018). It is better to evaluate species presence and survival globally. Locally, it is useful to identify new potentially colonizing species from equatorial direction and vulnerable species living at the equatorial end of their distribution that may go extinct (Kuussaari 2009). In many cases it would be a waste of resources to focus on saving these latter populations.

\section{Facilitate species to rearrange in space}

In transient communities, the ecosystem functions of species that are disappearing can be taken over by new species. The most evident way to enhance species introductions to 
transient communities is to protect, restore and increase landscape connectivity (Heller and Zavaleta 2009). This can be done in many ways, but halting large monoculture expanses and obstacles, while creating habitat corridors, steppingstones and green bridges (ecoducts) seems crucial. More advanced ways to improve connectivity are creating extra habitat in the overlapping area between current and predicted future habitat of vulnerable species (Grashof-Bokdam et al. 2009; Ruter et al. 2014; Vos 2008). In the context of transient communities, the potential mobility of co-determining community members should also be considered. Therefore, steppingstones and green bridges should be suitable for sets of interacting species, taking into account the mobility traits of the weakest disperser. Rates of these poleward expansions are likely determined by the slowest species. Increasing landscape connectivity may also facilitate the expansion of invasive species using the same landscape network. It will be a challenge to make the network selective for wanted and unwanted species (Saura et al. 2014).

Models of species range shifts show that larger populations will have greater potential for colonization because they produce more dispersing individuals. (Schippers et al. 2011; Wilson et al. 2010). So, maintaining high population size is also key for species mobility. In landscapes with large and permanent obstacles or when species are less mobile, it may be necessary to actively transport species poleward to new suitable habitats ('assisted colonization') (Heikkinen 2015; Hoegh-Guldberg et al. 2008; Richardson 2009). Richardson et al. (2009) developed a multi-criterium framework based on focal impact, collateral impact, feasibility and acceptability to evaluate the potential value and succes of assisted colonization (Richardson et al. 2009). In the context of transient communities, we can transport a group of interacting species simultaneously to avoid unsuccessful introductions due to lack of facilitating species (e.g. prey or pollinators). On the other hand, introduction can be sequentially performed with the lowest trophic levels first, e.g. plants, herbivores, carnivores, parasites. Evidently, transported species might become invasive (Lunt 2013). However, assisted colonization has the advantage over connectivity improvements because transporting species can be selected which makes it possible to avoid species with invasive properties (Richardson et al. 2009). More research on assisted colonization and species interactions is needed to facilitate successful poleward expansion of immobile species.

\section{Increase ecosystem resilience}

To reduce the species loss in transient communities we should improve the local resilience of populations (Cote and Darling 2010; Moritz and Agudo 2013; Prober 2012). This can be done by increasing habitat patch sizes, allowing for more robust populations (FernandezChacon et al. 2014; Verboom et al. 2001) that are less vulnerable to extinctions (Verboom et al. 2010) and better able to survive sub-optimal conditions. Population size also affects the potential for adaptive evolution, although here it's less clear that a larger population is always superior because small or disjunct populations may adapt faster. Another way to preserve ecosystem resilience is by maintaining or improving the spatial and topographic heterogeneity of the landscape (Lawler et al. 2015; Maclean et al. 2017; Perovic 2015; Schippers et al. 2015b; Suggitt, 2018). For example, by maximizing elevational and other environmental gradients, and adding blue or green infrastructure. The added value of such landscapes is that increased heterogeneity creates ecotones and edges. This allows for more species per functional group and genetic variation, both increasing ecosystem resilience (Anderson et al. 2014). Restoration of ecosystems should focus on creating both macro- and micro-refugia that help species to survive through short-term climatic extremes 
(Harvey et al. 2020; Selwood and Zimmer 2020; Thakur et al. 2020). Given the concept of transient communities, it may be best to increase the resilience of the landscape with respect to keystone species that play an important role in the ecosystem.

\section{Conclusion}

Conservation efforts with respect to climate change often target individual species in response to abiotic climate change, but it is important to acknowledge that multiple interactions in food webs and communities underpin the functioning of ecological communities (Early and Keith 2019; Naeem et al. 1999; Ponisio, 2019). From the perspective of transient communities, conservation management should, therefore, scale up single species approaches to focus on communities, and consider the vulnerability of species in relation to their function in the community. One of the major challenges in elucidating the effects of climate change on biodiversity is that responses invariably must focus on interactive effects rather than on individual species. Species do not exist in isolation, they interact in a complex array of ways with other species that cover variable scales from the levels of trophic chains to more diffuse effects at the level of communities and ecosystems. Ecologist Daniel Janzen (Janzen 1974) once argued that the "most insidious sort of extinction [is] the extinction of ecological interactions", a point driven home more recently by Memmott et al. (2010), Memmott et al. (2010) and Valiente-Banuet (2015), Valiente-Banuet et al. (2015). Hence, science should identify crucial trophic and competitive or facilitative species interactions and value species interdependency and vulnerability with respect to climate change, while conservation efforts should shift from restoring the past to facilitating an unfolding a biodiversity-rich future.

Acknowledgements We thank David Ackerly and an anonymous reviewer for their helpful comments on this manuscript.

Authors contributions ELA and PS started this research; all authors contributed to text, references and ideas from their own field of expertise; PS led the literature search and the writing.

Funding This research was not funded by a specific organisation.

\section{Declarations}

Conflict of interest There were no conflicts of interest.

Open Access This article is licensed under a Creative Commons Attribution 4.0 International License, which permits use, sharing, adaptation, distribution and reproduction in any medium or format, as long as you give appropriate credit to the original author(s) and the source, provide a link to the Creative Commons licence, and indicate if changes were made. The images or other third party material in this article are included in the article's Creative Commons licence, unless indicated otherwise in a credit line to the material. If material is not included in the article's Creative Commons licence and your intended use is not permitted by statutory regulation or exceeds the permitted use, you will need to obtain permission directly from the copyright holder. To view a copy of this licence, visit http://creativecommons.org/licenses/by/4.0/. 


\section{References}

Alexander JM, Diez JM, Levine JM (2015) Novel competitors shape species' responses to climate change. Nature 525:515-518. https://doi.org/10.1038/nature14952

Amigo I (2020) When will the Amazon hit a tipping point? Nature 578:505-507. https://doi.org/10.1038/ d41586-020-00508-4

Anderson MG, Clark M, Sheldon AO (2014) Estimating climate resilience for conservation across geophysical settings. Conserv Biol 28:959-970. https://doi.org/10.1111/cobi.12272

Angert AL, Bontrager MG, Aringgren J (2020) What do we really know about adaptation at range edges? Annu Rev Ecol Evol Syst. https://doi.org/10.1146/annurev-ecolsys-012120-091002

Araujo MB, Thuiller W, Pearson RG (2006) Climate warming and the decline of amphibians and reptiles in Europe. J Biogeogr 33:1712-1728. https://doi.org/10.1111/j.1365-2699.2006.01482.x

Arevall J, Early R, Estrada A, Wennergren U, Eklof AC (2018) Conditions for successful range shifts under climate change: the role of species dispersal and landscape configuration. Divers Distrib 24:1598-1611. https://doi.org/10.1111/ddi.12793

Battipaglia G, Saurer M, Cherubini P, Calfapietra C, McCarthy HR, Norby RJ, Cotrufo MF (2013) Elevated $\mathrm{CO}_{2}$ increases tree-level intrinsic water use efficiency: insights from carbon and oxygen isotope analyses in tree rings across three forest FACE sites. New Phytol 197:544-554. https://doi. org/10.1111/nph.12044

Bond WJ, Midgley GF, Woodward FI (2003) The importance of low atmospheric $\mathrm{CO}_{2}$ and fire in promoting the spread of grasslands and savannas. Glob Change Biol 9:973-982. https://doi.org/10. 1046/j.1365-2486.2003.00577.x

Bonebrake TC et al (2018) Managing consequences of climate-driven species redistribution requires integration of ecology, conservation and social science. Biol Rev 93:284-305. https://doi.org/10. 1111/brv. 12344

Both C, Bouwhuis S, Lessells CM, Visser ME (2006) Climate change and population declines in a longdistance migratory bird. Nature 441:81-83. https://doi.org/10.1038/nature04539

Bourne EC, Bocedi G, Travis JMJ, Pakeman RJ, Brooker RW, Schiffers K (2014) Between migration load and evolutionary rescue: dispersal, adaptation and the response of spatially structured populations to environmental change. Proc R Soc B. https://doi.org/10.1098/rspb.2013.2795

Bowers MA, Harris LC (1994) A large-scale metapopulation model of interspecific competition and environmental-change. Ecol Model 72:251-273

Bowler DE et al (2017) Cross-realm assessment of climate change impacts on species' abundance trends. Nat Ecol Evol. https://doi.org/10.1038/s41559-016-0067

Brambilla M et al (2020) Species interactions and climate change: how the disruption of species cooccurrence will impact on an avian forest guild. Glob Change Biol 26:1212-1224. https://doi.org/ 10.1111/gcb. 14953

Brooker RW, Travis JMJ, Clark EJ, Dytham C (2007) Modelling species' range shifts in a changing climate: the impacts of biotic interactions, dispersal distance and the rate of climate change. $\mathrm{J}$ Theor Biol 245:59-65. https://doi.org/10.1016/j.jtbi.2006.09.033

Butterfield BJ, Anderson RS, Holmgren CA, Betancourt JL (2019) Extinction debt and delayed colonization have had comparable but unique effects on plant community-climate lags since the last glacial maximum. Glob Ecol Biogeogr 28:1067-1077. https://doi.org/10.1111/geb.12915

Carrasco D et al (2018) With or without you: Effects of the concurrent range expansion of an herbivore and its natural enemy on native species interactions. Glob Change Biol 24:631-643. https://doi. org/10.1111/gcb.13836

Cenci S, Saavedra S (2019) Non-Parametric Estimation of the Structural Stability of Non-Equilibrium Community Dynamics. Nat Ecol Evol 3:912-918. https://doi.org/10.1038/s41559-019-0879-1

Cerrato C, Lai V, Balletto E, Bonelli S (2016) Direct and indirect effects of weather variability in a specialist butterfly. Ecol Entomol 41:263-275. https://doi.org/10.1111/een.12296

Charmantier A, McCleery RH, Cole LR, Perrins C, Kruuk LEB, Sheldon BC (2008) Adaptive phenotypic plasticity in response to climate change in a wild bird population. Science 320:800-803. https://doi.org/10.1126/science. 1157174

Chown SL, Slabber S, McGeoch MA, Janion C, Leinaas HP (2007) Phenotypic plasticity mediates climate change responses among invasive and indigenous arthropods. Proc R Soc B 274:2531-2537. https://doi.org/10.1098/rspb.2007.0772

Cobben MMP, Verboom J, Opdam PFM, Hoekstra RF, Jochem R, Arens P, Smulders MJM (2011) Projected climate change causes loss and redistribution of genetic diversity in a model metapopulation of a medium-good disperser. Ecography 34:920-932. https://doi.org/10.1111/j.1600-0587. 2011.06713.x 
Cobben MMP, Verboom J, Opdam PFM, Hoekstra RF, Jochem R, Smulders MJM (2015) Spatial sorting and range shifts: consequences for evolutionary potential and genetic signature of a dispersal trait. J Theor Biol 373:92-99. https://doi.org/10.1016/j.jtbi.2015.03.019

Cormont A, Malinowska AH, Kostenko O, Radchuk V, Hemerik L, WallisDeVries MF, Verboom J (2011) Effect of local weather on butterfly flight behaviour, movement, and colonization: significance for dispersal under climate change. Biodivers Conserv 20:483-503. https://doi.org/10.1007/ s10531-010-9960-4

Cote IM, Darling ES (2010) Rethinking ecosystem resilience in the face of climate change. PLoS Biol. https://doi.org/10.1371/journal.pbio.1000438

Coumou D, Rahmstorf S (2012) A decade of weather extremes. Nat Clim Change 2:491-496. https://doi. org/10.1038/nclimate1452

Davis AJ, Lawton JH, Shorrocks B, Jenkinson LS (1998) Individualistic species responses invalidate simple physiological models of community dynamics under global environmental change. J Anim Ecol 67:600-612. https://doi.org/10.1046/j.1365-2656.1998.00223.x

Demastes JW, Hafner DJ, Hafner MS, Light JE, Spradling TA (2019) Loss of genetic diversity, recovery and allele surfing in a colonizing parasite, Geomydoecus Aurei. Mol Ecol 28:703-720. https://doi.org/10. $1111 / \mathrm{mec} .14997$

Drake BG, GonzalezMeler MA, Long SP (1997) More efficient plants: a consequence of rising atmospheric $\mathrm{CO}_{2}$ ? Annu Rev Plant Physiol Plant Mol Biol 48:609-639. https://doi.org/10.1146/annurev.arplant. 48.1.609

Dunne JA, Williams RJ (2009) Cascading extinctions and community collapse in model food webs. Philos Trans R Soc B 364:1711-1723. https://doi.org/10.1098/rstb.2008.0219

Early R, Keith SA (2019) Geographically variable biotic interactions and implications for species ranges. Glob Ecol Biogeogr 28:42-53. https://doi.org/10.1111/geb.12861

Easterling DR, Meehl GA, Parmesan C, Changnon SA, Karl TR, Mearns LO (2000) Climate extremes: observations, modeling, and impacts. Science 289:2068-2074. https://doi.org/10.1126/science.289. 5487.2068

Engelhardt EK, Neuschulz EL, Hof C (2020) Ignoring biotic interactions overestimates climate change effects: the potential response of the spotted nutcracker to changes in climate and resource plants. J Biogeogr 47:143-154. https://doi.org/10.1111/jbi.13699

Essens T, van Langevelde F, Vos RA, Van Swaay CAM, WallisDeVries MF (2017) Ecological determinants of butterfly vulnerability across the European continent. J Insect Conserv 21:439-450. https://doi.org/ 10.1007/s10841-017-9972-4

Etterson JR, Shaw RG (2001) Constraint to adaptive evolution in response to global warming. Science 294:151-154. https://doi.org/10.1126/science.1063656

Excoffier L, Foll M, Petit RJ (2009) Genetic consequences of range expansions. Annu Rev Ecol Evol Syst 40:481-501. https://doi.org/10.1146/annurev.ecolsys.39.110707.173414

Felton AJ, Knapp AK, Smith MD (2020) Precipitation-productivity relationships and the duration of precipitation anomalies: an underappreciated dimension of climate change. Glob Change Biol. https:// doi.org/10.1111/gcb. 15480

Fernandez-Chacon A et al (2014) Determinants of extinction-colonization dynamics in Mediterranean butterflies: the role of landscape, climate and local habitat features. J Anim Ecol 83:276-285. https://doi. org/10.1111/1365-2656.12118

Foden WB et al (2019) Climate change vulnerability assessment of species. Wiley Interdiscip Rev-Clim Change. https://doi.org/10.1002/wcc.551

Franco AMA et al (2006) Impacts of climate warming and habitat loss on extinctions at species' low-latitude range boundaries. Glob Change Biol 12:1545-1553. https://doi.org/10.1111/j.1365-2486.2006. 01180.x

Gilman SE, Urban MC, Tewksbury J, Gilchrist GW, Holt RD (2010) A framework for community interactions under climate change. Trends Ecol Evol 25:325-331. https://doi.org/10.1016/j.tree.2010.03.002

Grashof-Bokdam CJ, Chardon JP, Vos CC, Foppen RPB, WallisDeVries M, van der Veen M, Meeuwsen HAM (2009) The synergistic effect of combining woodlands and green veining for biodiversity. Landsc Ecol 24:1105-1121. https://doi.org/10.1007/s10980-008-9274-Z

Green RE, Collingham YC, Willis SG, Gregory RD, Smith KW, Huntley B (2008) Performance of climate envelope models in retrodicting recent changes in bird population size from observed climatic change. Biol Lett 4:599-602. https://doi.org/10.1098/rsbl.2008.0052

Griffiths RA, Sewell D, McCrea RS (2010) Dynamics of a declining amphibian metapopulation: survival, dispersal and the impact of climate. Biol Conserv 143:485-491. https://doi.org/10.1016/j.biocon. 2009.11.017 
Gripenberg S, Hamer N, Brereton T, Roy DB, Lewis OT (2011) A novel parasitoid and a declining butterfly: cause or coincidence? Ecol Entomol 36:271-281. https://doi.org/10.1111/j.1365-2311.2011.01269.x

Halpin PN (1997) Global climate change and natural-area protection: management responses and research directions. Ecol Appl 7:828-843

Hance T, van Baaren J, Vernon P, Boivin G (2007) Impact of extreme temperatures on parasitoids in a climate change perspective. Annu Rev Entomol 52:107-126. https://doi.org/10.1146/annurev.ento.52. 110405.091333

Harris JE, Rodenhouse NL, Holmes RT (2019) Decline in beetle abundance and diversity in an intact temperate forest linked to climate warming. Biol Conserv. https://doi.org/10.1016/j.biocon.2019.108219

Harmon JP, Moran NA, Ives AR (2009) Species response to environmental change: impacts of food web interactions and evolution. Science 323:1347-1350. https://doi.org/10.1126/science.1167396

Harrison PA, Berry PM, Butt N, New M (2006) Modelling climate change impacts on species' distributions at the European scale: implications for conservation policy. Environ Sci Policy 9:116-128

Harvey JA (2015) Conserving host-parasitoid interactions in a warming world current opinion in insect. Science 12:79-85. https://doi.org/10.1016/j.cois.2015.09.001

Harvey JA, Heinen R, Gols R, Thakur MP (2020) Climate change-mediated temperature extremes and insects: From outbreaks to breakdowns. Glob Change Biol 26:6685-6701. https://doi.org/10.1111/ gcb. 15377

Heikkinen RK et al (2015) Modelling potential success of conservation translocations of a specialist grassland butterfly. Biol Conserv 192:200-206. https://doi.org/10.1016/j.biocon.2015.09.028

Heller NE, Zavaleta ES (2009) Biodiversity management in the face of climate change: a review of 22 years of recommendations. Biol Conserv 142:14-32. https://doi.org/10.1016/j.biocon.2008.10.006

Hickling R, Roy DB, Hill JK, Fox R, Thomas CD (2006) The distributions of a wide range of taxonomic groups are expanding polewards. Glob Change Biol 12:450-455. https://doi.org/10.1111/j.1365-2486. 2006.01116.x

Hill NJ, Tobin AJ, Reside AE, Pepperell JG, Bridge TCL (2016) Dynamic habitat suitability modelling reveals rapid poleward distribution shift in a mobile apex predator. Glob Change Biol 22:1086-1096. https://doi.org/10.1111/gcb.13129

Hobbs RJ et al (2006) Novel ecosystems: theoretical and management aspects of the new ecological world order. Glob Ecol Biogeogr 15:1-7. https://doi.org/10.1111/j.1466-822X.2006.00212.x

Hobbs RJ, Higgs E, Harris JA (2009) Novel ecosystems: implications for conservation and restoration. Trends Ecol Evol 24:599-605. https://doi.org/10.1016/j.tree.2009.05.012

Hoegh-Guldberg O, Hughes L, McIntyre S, Lindenmayer DB, Parmesan C, Possingham HP, Thomas CD (2008) Assisted colonization and rapid climate change. Science 321:345-346. https://doi.org/10. $1126 /$ science. 1157897

Hoffmann S, Irl SDH, Beierkuhnlein C (2019) Predicted climate shifts within terrestrial protected areas worldwide. Nat Commun. https://doi.org/10.1038/s41467-019-12603-w

Holt RD (2003) On the evolutionary ecology of species' ranges. Evol Ecol Res 5:159-178

Huang W, Houlton BZ, Marklein AR, Liu J, Zhou G (2015) Plant stoichiometric responses to elevated $\mathrm{CO}_{2}$ vary with nitrogen and phosphorus inputs: evidence from a global-scale meta-analysis. Sci Rep. https://doi.org/10.1038/srep18225

Hubbell SP (2005) Neutral theory in community ecology and the hypothesis of functional equivalence. Funct Ecol 19:166-172. https://doi.org/10.1111/j.0269-8463.2005.00965.x

Hulme PE (2005) Adapting to climate change: is there scope for ecological management in the face of a global threat? J Appl Ecol 42:784-794. https://doi.org/10.1111/j.1365-2664.2005.01082.x

Illan JG, Thomas CD, Jones JA, Wong WK, Shirley SM, Betts MG (2014) Precipitation and winter temperature predict long-term range-scale abundance changes in Western North American birds. Glob Change Biol 20:3351-3364. https://doi.org/10.1111/gcb.12642

Ings TC et al (2009) Ecological networks-beyond food webs. J Anim Ecol 78:253-269. https://doi.org/10. 1111/j.1365-2656.2008.01460.x

IPCC (2014) Fifth assesment report (AR5), climate change 2014: synthesis report. IPCC, Geneva

IPCC (2019) Climate change and land: an IPCC special report on climate change, desertification, land degradation, sustainable land management, food security, and greenhouse gas fluxes in terrestrial ecosystems (summary for policymakers). IPCC, Geneva

Janzen DH (1974) Deflowering of central-America. Nat Hist 83:48-53

Jiang MK et al (2020) The fate of carbon in a mature forest under carbon dioxide enrichment. Nature 580:227-231. https://doi.org/10.1038/s41586-020-2128-9

Jiguet F, Julliard R, Thomas CD, Dehorter O, Newson SE, Couvet D (2006) Thermal range predicts bird population resilience to extreme high temperatures. Ecol Lett 9:1321-1330. https://doi.org/10.1111/j. 1461-0248.2006.00986.x 
Jorgenson MT et al (2010) Resilience and vulnerability of permafrost to climate change. Can J for Res 40:1219-1236. https://doi.org/10.1139/x10-060

Kaur T, Dutta PS (2020) Persistence and stability of interacting species in response to climate warming: the role of trophic structure. Theor Ecol. https://doi.org/10.1007/s12080-020-00456-9

Keith DA et al (2008) Predicting extinction risks under climate change: coupling stochastic population models with dynamic bioclimatic habitat models. Biol Lett 4:560-563. https://doi.org/10.1098/rsb1.2008. 0049

Keith SA, Herbert RJH, Norton PA, Hawkins SJ, Newton AC (2011) Individualistic species limitations of climate-induced range expansions generated by meso-scale dispersal barriers. Divers Distrib 17:275286. https://doi.org/10.1111/j.1472-4642.2010.00734.x

Kendon EJ, Roberts NM, Fowler HJ, Roberts MJ, Chan SC, Senior CA (2014) Heavier summer downpours with climate change revealed by weather forecast resolution model. Nat Clim Change 4:570-576. https://doi.org/10.1038/nclimate2258

Kinnison MT, Hendry AP (2001) The pace of modern life II: from rates of contemporary microevolution to pattern and process. Genetica 112:145-164. https://doi.org/10.1023/a:1013375419520

Klanderud K (2005) Climate change effects on species interactions in an alpine plant community. J Ecol 93:127-137. https://doi.org/10.1111/j.1365-2745.2004.00944.x

Kovac M, Hladnik D, Kutnar L (2018) Biodiversity in (the Natura 2000) forest habitats is not static: its conservation calls for an active management approach. J Nat Conserv 43:250-260. https://doi.org/10. 1016/j.jnc.2017.07.004

Kuhn E, Gegout JC (2019) Highlighting declines of cold-demanding plant species in lowlands under climate warming. Ecography 42:36-44. https://doi.org/10.1111/ecog.03469

Kuussaari $\mathrm{M}$ et al (2009) Extinction debt: a challenge for biodiversity conservation. Trends Ecol Evol 24:564-571

Lasky JR (2019) Eco-evolutionary community turnover following environmental change. Evol Appl 12:1434-1448. https://doi.org/10.1111/eva.12776

Lawler JJ (2009) Climate change adaptation strategies for resource management and conservation planning. In: Ostfeld RS, Schlesinger WH (Eds) Year in ecology and conservation biology Ann N Y Acad Sci 1162:79-98. https://doi.org/10.1111/j.1749-6632.2009.04147.x

Lawler JJ, Shafer SL, White D, Kareiva P, Maurer EP, Blaustein AR, Bartlein PJ (2009) Projected climateinduced faunal change in the western hemisphere. Ecology 90:588-597. https://doi.org/10.1890/ 08-0823.1

Lawler JJ, Ackerly DD, Albano CM, Anderson MG, Dobrowski SZ, Gill JL, Heller NE, Pressey RL, Sanderson EW, Weiss SB (2015) The theory behind, and the challenges of, conserving nature's stage in a time of rapid change. Conserv Biol 29:618-629. https://doi.org/10.1111/cobi.12505

Lawson CR, Vindenes Y, Bailey L, van de Pol M (2015) Environmental variation and population responses to global change. Ecol Lett 18:724-736. https://doi.org/10.1111/ele.12437

Lee-Yaw JA, Fracassetti M, Willi Y (2018) Environmental marginality and geographic range limits: a case study with Arabidopsis lyrata ssp lyrata. Ecography 41:622-634. https://doi.org/10.1111/ecog.02869

Lenoir J, Svenning JC (2015) Climate-related range shifts-a global multidimensional synthesis and new research directions. Ecography 38:15-28. https://doi.org/10.1111/ecog.00967

Lindner $\mathrm{M}$ et al (2010) Climate change impacts, adaptive capacity, and vulnerability of European forest ecosystems. For Ecol Manage 259:698-709. https://doi.org/10.1016/j.foreco.2009.09.023

Lloyd J, Farquhar GD (2008) Effects of rising temperatures and $\mathrm{CO}_{2}$ on the physiology of tropical forest trees. Philos Trans R Soc B 363:1811-1817. https://doi.org/10.1098/rstb.2007.0032

Logan SA, Phuekvilai P, Sanderson R, Wolff K (2019) Reproductive and population genetic characteristics of leading-edge and central populations of two temperate forest tree species and implications for range expansion. For Ecol Manage 433:475-486. https://doi.org/10.1016/j.foreco.2018.11.024

Lunt ID et al (2013) Using assisted colonisation to conserve biodiversity and restore ecosystem function under climate change. Biol Conserv 157:172-177. https://doi.org/10.1016/j.biocon.2012.08.034

Lurgi M, Lopez BC, Montoya JM (2012) Climate change impacts on body size and food web structure on mountain ecosystems. Philos Trans R Soc B 367:3050-3057. https://doi.org/10.1098/rstb.2012.0239

Maclean IMD, Suggitt AJ, Wilson RJ, Duffy JP, Bennie JJ (2017) Fine-scale climate change: modelling spatial variation in biologically meaningful rates of warming. Glob Change Biol 23:256-268. https:// doi.org/10.1111/gcb.13343

MacLean SA, Beissinger SR (2017) Species' traits as predictors of range shifts under contemporary climate change: a review and meta-analysis. Glob Change Biol 23:4094-4105. https://doi.org/10.1111/gcb. 13736 
Mason SC, Palmer G, Fox R, Gillings S, Hill JK, Thomas CD, Oliver TH (2015) Geographical range margins of many taxonomic groups continue to shift polewards. Biol J Lin Soc 115:586-597. https://doi. org/10.1111/bij.12574

Matesanz S, Ramirez-Valiente JA (2019) A review and meta-analysis of intraspecific differences in phenotypic plasticity: implications to forecast plant responses to climate change. Glob Ecol Biogeogr 28:1682-1694. https://doi.org/10.1111/geb.12972

Matthews SN, Iverson LR, Prasad AM, Peters MP (2011) Changes in potential habitat of 147 North American breeding bird species in response to redistribution of trees and climate following predicted climate change. Ecography 34:933-945. https://doi.org/10.1111/j.1600-0587.2011.06803.x

Meester LD, Stoks R, Brans KI (2018) Genetic adaptation as a biological buffer against climate change: potential and limitations. Integr Zoology 13:372-391. https://doi.org/10.1111/1749-4877.12298

Memmott J, Craze PG, Waser NM, Price MV (2007) Global warming and the disruption of plant-pollinator interactions. Ecol Lett 10:710-717. https://doi.org/10.1111/j.1461-0248.2007.01061.x

Memmott J, Cadotte M, Hulme PE, Kerby G, Milner-Gulland EJ, Whittingham MJ (2010) Putting applied ecology into practice. J Appl Ecol 47:1-4. https://doi.org/10.1111/j.1365-2664.2009. 01757.x

Menendez R, Gonzalez-Megias A, Lewis OT, Shaw MR, Thomas CD (2008) Escape from natural enemies during climate-driven range expansion: a case study. Ecol Entomol 33:413-421. https://doi. org/10.1111/j.1365-2311.2008.00985.x

Merila J (2012) Evolution in response to climate change: in pursuit of the missing evidence. BioEssays 34:811-818. https://doi.org/10.1002/bies.201200054

Moritz C, Agudo R (2013) The future of species under climate change: resilience or decline? Science 341:504-508. https://doi.org/10.1126/science.1237190

Myhre G et al (2019) Frequency of extreme precipitation increases extensively with event rareness under global warming. Sci Rep. https://doi.org/10.1038/s41598-019-52277-4

Nadeau CP, Urban MC (2019) Eco-evolution on the edge during climate change. Ecography 42:12801297. https://doi.org/10.1111/ecog.04404

Naeem S, Tjossem SF, Byers D, Bristow C, Li SB (1999) Plant neighborhood diversity and production. Ecoscience 6:355-365

O’Connor B, Bojinski S, Röösli C, Schaepman ME (2020) Monitoring global changes in biodiversity and climate essential as ecological crisis intensifies. Ecol Inform. https://doi.org/10.1016/j.ecoinf. 2019.101033

Opdam P, Wascher D (2004) Climate change meets habitat fragmentation: linking landscape and biogeographical scale levels in research and conservation. Biol Conserv 117:285-297. https://doi.org/10. 1016/j.biocon.2003.11.008IISSN0006-3207

Osland MJ et al (2020) Temperature thresholds for black mangrove (Avicennia germinans) freeze damage, mortality and recovery in North America: refining tipping points for range expansion in a warming climate. J Ecol 108:654-665. https://doi.org/10.1111/1365-2745.13285

Parmesan C (2006) Ecological and evolutionary responses to recent climate change. Annu Rev Ecol Evol Syst 37:637-669. https://doi.org/10.1146/annurev.ecolsys.37.091305.110100

Parmesan C, Root TL, Willig MR (2000) Impacts of extreme weather and climate on terrestrial biota. Bull Am Meteor Soc 81:443-450. https://doi.org/10.1175/1520-0477(2000)081\%3c0443:ioewac\% 3e2.3.co;2

Parmesan C et al (1999) Poleward shifts in geographical ranges of butterfly species associated with regional warming. Nature 399:579-583

Pearson RG, Dawson TP (2003) Predicting the impacts of climate change on the distribution of species: are bioclimate envelope models useful? Glob Ecol Biogeogr 12:361-371. https://doi.org/10. 1046/j.1466-822X.2003.00042.x

Penuelas J, Hunt JM, Ogaya R, Jump AS (2008) Twentieth century changes of tree-ring delta C-13 at the southern range-edge of Fagus sylvatica: increasing water-use efficiency does not avoid the growth decline induced by warming at low altitudes. Glob Change Biol 14:1076-1088. https://doi.org/10. 1111/j.1365-2486.2008.01563.x

Perovic D et al (2015) Configurational landscape heterogeneity shapes functional community composition of grassland butterflies. J Appl Ecol 52:505-513. https://doi.org/10.1111/1365-2664.12394

Ponisio LC et al (2019) A network perspective for community assembly. Front Ecol Evol. https://doi.org/ $10.3389 /$ fevo.2019.00103

Poorter $\mathrm{H}$ (1993) Interspecific variation in the growth-response of plants to an elevated ambient $\mathrm{CO}_{2}$ concentration. Vegetatio 104:77-97. https://doi.org/10.1007/bf00048146 
Preston K, Rotenberry JT, Redak RA, Allen MF (2008) Habitat shifts of endangered species under altered climate conditions: importance of biotic interactions. Glob Change Biol 14:2501-2515. https://doi.org/10.1111/j.1365-2486.2008.01671.x

Prober SM et al (2012) Facilitating adaptation of biodiversity to climate change: a conceptual framework applied to the world's largest mediterranean-climate woodland. Clim Change 110:227-248. https://doi.org/10.1007/s10584-011-0092-y

Randerson JT et al (2006) The impact of boreal forest fire on climate warming. Science 314:1130-1132. https://doi.org/10.1126/science.1132075

Razgour O et al (2019) Considering adaptive genetic variation in climate change vulnerability assessment reduces species range loss projections. Proc Natl Acad Sci USA 116:10418-10423. https:// doi.org/10.1073/pnas.1820663116

Rehm EM, Olivas P, Stroud J, Feeley KJ (2015) Losing your edge: climate change and the conservation value of range-edge populations. Ecol Evol 5:4315-4326. https://doi.org/10.1002/ece3.1645

Richards CL et al (2017) Ecological plant epigenetics: evidence from model and non-model species, and the way forward. Ecol Lett 20:1576-1590. https://doi.org/10.1111/ele.12858

Richardson DM et al (2009) Multidimensional evaluation of managed relocation. Proc Natl Acad Sci USA 106:9721-9724. https://doi.org/10.1073/pnas.0902327106

Robillard CM, Coristine LE, Soares RN, Kerr JT (2015) Facilitating climate-change-induced range shifts across continental land-use barriers. Conserv Biol 29:1586-1595. https://doi.org/10.1111/cobi.12556

Roratto PA, Fernandes FA, de Freitas TRO (2015) Phylogeography of the subterranean rodent Ctenomys torquatus: an evaluation of the riverine barrier hypothesis. J Biogeogr 42:694-705. https://doi.org/10. 1111/jbi.12460

Rumpf SB et al (2019) Extinction debts and colonization credits of non-forest plants in the European Alps. Nat Commun. https://doi.org/10.1038/s41467-019-12343-X

Ruter S, Vos CC, van Eupen M, Ruhmkorf H (2014) Transboundary ecological networks as an adaptation strategy to climate change: the example of the Dutch—German border. Basic Appl Ecol 15:639-650. https://doi.org/10.1016/j.baae.2014.09.007

Saura S, Bodin O, Fortin MJ (2014) Stepping stones are crucial for species' long-distance dispersal and range expansion through habitat networks. J Appl Ecol 51:171-182. https://doi.org/10.1111/13652664.12179

Scheffer M, Carpenter S, Foley JA, Folke C, Walker B (2001) Catastrophic shifts in ecosystems. Nature 413:591-596. https://doi.org/10.1038/35098000

Schippers P, Sterck F, Vlam M, Zuidema PA (2015a) Tree growth variation in the tropical forest: understanding effects of temperature, rainfall and $\mathrm{CO}_{2}$. Glob Change Biol 21:2749-2761. https://doi.org/ 10.1111/gcb. 12877

Schippers P et al (2015b) Landscape diversity enhances the resilience of populations, ecosystems and local economy in rural areas. Landsc Ecol 30:193-202. https://doi.org/10.1007/s10980-014-0136-6

Schippers P, Verboom J, Vos CC, Jochem R (2011) Metapopulation shift and survival of woodland birds under climate change: will species be able to track? Ecography 34:909-919. https://doi.org/10.1111/j. 1600-0587.2011.06712.x

Schittko C et al (2020) A multidimensional framework for measuring biotic novelty: how novel is a community? Glob Change Biol 26:4401-4417. https://doi.org/10.1111/gcb.15140

Schleuning $\mathrm{M}$ et al (2016) Ecological networks are more sensitive to plant than to animal extinction under climate change. Nat Commun. https://doi.org/10.1038/ncomms13965

Schweiger O, Settele J, Kudrna O, Klotz S, Kuhn I (2008) Climate change can cause spatial mismatch of trophically interacting species. Ecology 89:3472-3479. https://doi.org/10.1890/07-1748.1

Seebacher F, White CR, Franklin CE (2015) Physiological plasticity increases resilience of ectothermic animals to climate change. Nat Clim Change 5:61-66. https://doi.org/10.1038/nclimate2457

Selwood KE, Zimmer HC (2020) Refuges for biodiversity conservation: a review of the evidence. Biol Conserv. https://doi.org/10.1016/j.biocon.2020.108502

Shine R, Brown GP, Phillips BL (2011) An evolutionary process that assembles phenotypes through space rather than through time. Proc Natl Acad Sci USA 108:5708-5711. https://doi.org/10.1073/pnas. 1018989108

Skelly DK, Joseph LN, Possingham HP, Freidenburg LK, Farrugia TJ, Kinnison MT, Hendry AP (2007) Evolutionary responses to climate change. Conserv Biol 21:1353-1355. https://doi.org/10.1111/j. 1523-1739.2007.00764.x

Soh WK et al (2019) Rising CO2 drives divergence in water use efficiency of evergreen and deciduous plants. Sci Adv. https://doi.org/10.1126/sciadv.aax7906 
Sonesson M, Carlsson BA, Callaghan TV, Halling S, Bjorn LO, Bertgren M, Johanson U (2002) Growth of two peat-forming mosses in subarctic mires: species interactions and effects of simulated climate change. Oikos 99:151-160. https://doi.org/10.1034/j.1600-0706.2002.990115.x

Suggitt AJ et al (2017) Conducting robust ecological analyses with climate data. Oikos 126:1533-1541. https://doi.org/10.1111/oik.04203

Suggitt AJ et al (2018) Extinction risk from climate change is reduced by microclimatic buffering. Nat Clim Change 8:713-717. https://doi.org/10.1038/s41558-018-0231-9

Suttle KB, Thomsen MA, Power ME (2007) Species interactions reverse grassland responses to changing climate. Science 315:640-642. https://doi.org/10.1126/science.1136401

Thakur MP, Bakker ES, Veen GC, Harvey JA (2020) Climate extremes, rewilding, and the role of microhabitats. One Earth 2:506-509

Thomas CD, Franco AMA, Hill JK (2006) Range retractions and extinction in the face of climate warming. Trends Ecol Evol 21:415-416. https://doi.org/10.1016/j.tree.2006.05.012

Tilman D, May RM, Lehman CL, Nowak MA (1994) Habitat destruction and the extinction debt. Nature 371:65-66

Tomiolo S, Ward D (2018) Species migrations and range shifts: a synthesis of causes and consequences. Perspect Plant Ecol Evol Syst 33:62-77. https://doi.org/10.1016/j.ppees.2018.06.001

Travis JMJ (2003) Climate change and habitat destruction: a deadly anthropogenic cocktail. Proc R Soc Lond Ser B 270:467-473

Travis JMJ, Munkemuller T, Burton OJ, Best A, Dytham C, Johst K (2007) Deleterious mutations can surf to high densities on the wave front of an expanding population. Mol Biol Evol 24:2334-2343. https:// doi.org/10.1093/molbev/msm167

Tylianakis JM, Didham RK, Bascompte J, Wardle DA (2008) Global change and species interactions in terrestrial ecosystems. Ecol Lett 11:1351-1363. https://doi.org/10.1111/j.1461-0248.2008.01250.x

Valiente-Banuet A et al (2015) Beyond species loss: the extinction of ecological interactions in a changing world. Funct Ecol 29:299-307. https://doi.org/10.1111/1365-2435.12356

van Asch M, Salis L, Holleman LJM, van Lith B, Visser ME (2013) Evolutionary response of the egg hatching date of a herbivorous insect under climate change. Nat Clim Change 3:244-248. https://doi.org/ $10.1038 /$ nclimate 1717

Van der Putten WH, Macel M, Visser ME (2010) Predicting species distribution and abundance responses to climate change: why it is essential to include biotic interactions across trophic levels. Philos Trans R Soc B 365:2025-2034. https://doi.org/10.1098/rstb.2010.0037

Verboom J, Foppen R, Chardon P, Opdam P, Luttikhuizen P (2001) Introducing the key patch approach for habitat networks with persistent populations: an example for marshland birds. Biol Conserv 100:89-101

Verboom J, Schippers P, Cormont A, Sterk M, Vos CC, Opdam PFM (2010) Population dynamics under increasing environmental variability: implications of climate change for ecological network design criteria. Landsc Ecol 25:1289-1298. https://doi.org/10.1007/s10980-010-9497-7

Visser ME (2008) Keeping up with a warming world; assessing the rate of adaptation to climate change. Proc R Soc B 275:649-659. https://doi.org/10.1098/rspb.2007.0997

Visser ME, Gienapp P (2019) Evolutionary and demographic consequences of phenological mismatches. Nat Ecol Evol 3:879-885. https://doi.org/10.1038/s41559-019-0880-8

Visser ME, Holleman LJM, Caro SP (2009) Temperature has a causal effect on avian timing of reproduction. Proc R Soc B 276:2323-2331. https://doi.org/10.1098/rspb.2009.0213

Vos CC et al (2008) Adapting landscapes to climate change: examples of climate-proof ecosystem networks and priority adaptation zones. J Appl Ecol 45:1722-1731. https://doi.org/10.1111/j.1365-2664.2008. 01569.x

Waldock C, Dornelas M, Bates AE (2018) Temperature-driven biodiversity change: disentangling space and time. Bioscience 68:873-884

Wallisdevries MF, Van Swaay CAM (2006) Global warming and excess nitrogen may induce butterfly decline by microclimatic cooling. Glob Change Biol 12:1620-1626. https://doi.org/10.1111/j.13652486.2006.01202.x

Wand SJE, Midgley GF, Jones MH, Curtis PS (1999) Responses of wild C4 and C3 grass (Poaceae) species to elevated atmospheric $\mathrm{CO}_{2}$ concentration: a meta-analytic test of current theories and perceptions. Glob Change Biol 5:723-741. https://doi.org/10.1046/j.1365-2486.1999.00265.x

Warren R, Price J, VanDerWal J, Cornelius S, Sohl H (2018) The implications of the United Nations Paris Agreement on climate change for globally significant biodiversity areas. Clim Change 147:395-409. https://doi.org/10.1007/s10584-018-2158-6 
Welti EAR, Roeder KA, De Beurs KM, Joern A, Kaspari M (2020) Nutrient dilution and climate cycles underlie declines in a dominant insect herbivore. Proc Natl Acad Sci USA 117:7271-7275. https:// doi.org/10.1073/pnas.1920012117

Williams JW, Jackson ST (2007) Novel climates, no-analog communities, and ecological surprises. Front Ecol Environ 5:475-482. https://doi.org/10.1890/070037

Wilson RJ, Davies ZG, Thomas CD (2010) Linking habitat use to range expansion rates in fragmented landscapes: a metapopulation approach. Ecography 33:73-82. https://doi.org/10.1111/j.1600-0587.2009. 06038.x

Wittwer T, O'Hara RB, Caplat P, Hickler T, Smith HG (2015) Long-term population dynamics of a migrant bird suggests interaction of climate change and competition with resident species. Oikos 124:11511159. https://doi.org/10.1111/oik.01559

Woodward G, Brown LE, Edwards FK, Hudson LN, Milner AM, Reuman DC, Ledger ME (2012) Climate change impacts in multispecies systems: drought alters food web size structure in a field experiment. Philos Trans R Soc B 367:2990-2997. https://doi.org/10.1098/rstb.2012.0245

Wu ZT, Dijkstra P, Koch GW, Penuelas J, Hungate BA (2011) Responses of terrestrial ecosystems to temperature and precipitation change: a meta-analysis of experimental manipulation. Glob Change Biol 17:927-942. https://doi.org/10.1111/j.1365-2486.2010.02302.x

Yuan ZY, Chen HYH (2015) Decoupling of nitrogen and phosphorus in terrestrial plants associated with global changes. Nat Clim Change 5:465-469. https://doi.org/10.1038/nclimate2549

Zhang Q, Tang H, Cui F, Dai L (2019) SPEI-based analysis of drought characteristics and trends in Hulun Buir grassland Shengtai Xuebao/. Acta Ecol Sin 39:7110-7123. https://doi.org/10.5846/stxb201807 061481

Zhang C, Wang X, Li J, Hua T (2020) Identifying the effect of climate change on desertification in northern China via trend analysis of potential evapotranspiration and precipitation. Ecol Ind. https://doi.org/10. 1016/j.ecolind.2020.106141

Zhu H, Zou XH, Wang DL, Wan SQ, Wang L, Guo JX (2015) Responses of community-level plant-insect interactions to climate warming in a meadow steppe. Sci Rep. https://doi.org/10.1038/srep18654

Zotz G, Pepin S, Korner C (2005) No down-regulation of leaf photosynthesis in mature forest trees after three years of exposure to elevated $\mathrm{CO}_{2}$. Plant Biol 7:369-374. https://doi.org/10.1055/s-2005-837635

Publisher's Note Springer Nature remains neutral with regard to jurisdictional claims in published maps and institutional affiliations.

\section{Authors and Affiliations}

\section{Peter Schippers ${ }^{1}$ (D) Euridice Leyequien Abarca ${ }^{2}$ Jana Verboom ${ }^{1,3}$ (D) G. W. Wieger Wamelink ${ }^{1}$ (D) . Claire C. Vos $^{1} \cdot$ Willem F. de Boer ${ }^{4}$ (D) Jeffrey A. Harvey ${ }^{5,6}$ (D) . Tijl Essens ${ }^{7}$. Carla J. Grashof-Bokdam ${ }^{1}$. Michiel F. WallisDeVries ${ }^{8,9}$ (D) Marleen M. P. Cobben ${ }^{5,10}$}

Euridice Leyequien Abarca euridice.leyequienabarca@hvhl.nl

Jana Verboom

jana.verboom@wur.nl

G. W. Wieger Wamelink

wieger.wamelink@wur.nl

Claire C. Vos

clairecvos@gmail.com

Willem F. de Boer

fred.deboer@wur.nl

Jeffrey A. Harvey

J.Harvey@nioo.knaw.nl 
Tijl Essens

tijl.essens@gmail.com

Carla J. Grashof-Bokdam

carla.grashof@wur.nl

Michiel F. WallisDeVries

michiel.wallisdevries@wur.nl

Marleen M. P. Cobben

Marleen.Cobben@gmail.com

1 Wageningen Environmental Research, Wageningen University \& Research, P.O. Box 47, 6700 AA Wageningen, The Netherlands

2 Van Hall-Larenstein University of Applied Sciences, Velp, The Netherlands

3 Environmental Systems Analysis Group, Wageningen University \& Research, Wageningen, The Netherlands

4 Department of Resource Ecology, Wageningen University, Wageningen, The Netherlands

5 Department of Terrestrial Ecology, Netherlands Institute of Ecology, Wageningen, The Netherlands

6 Department of Ecological Sciences, Section Animal Ecology, VU University Amsterdam, Amsterdam, The Netherlands

7 Stichting Landschapsbeheer Gelderland, Rozendaal, The Netherlands

8 Department of Plant Ecology and Nature Conservation, Wageningen University, Wageningen, The Netherlands

$9 \quad$ De Vlinderstichting/Dutch Butterfly Conservation, Wageningen, The Netherlands

10 Theoretical Evolutionary Ecology Group, Würzburg University, Würzburg, Germany 